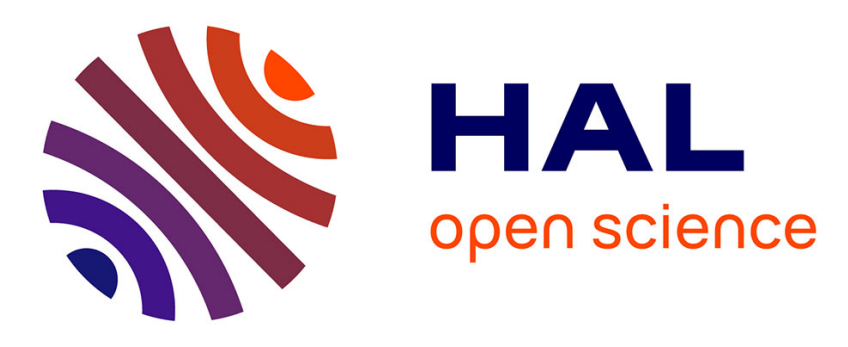

\title{
Sea lilies in spring: Crinoid diversification during the Early Ordovician
}

Thomas E Guensburg, James Sprinkle, Rich Mooi, Forest Gahn, Bertrand Lefebvre

\section{- To cite this version:}

Thomas E Guensburg, James Sprinkle, Rich Mooi, Forest Gahn, Bertrand Lefebvre. Sea lilies in spring: Crinoid diversification during the Early Ordovician. Paleontological Journal / Paleontologicheskii Zhurnal, 2021, 55, pp.985-992. 10.1134/S0031030121090045 . hal-03433589

\author{
HAL Id: hal-03433589 \\ https://hal.science/hal-03433589
}

Submitted on 17 Nov 2021

HAL is a multi-disciplinary open access archive for the deposit and dissemination of scientific research documents, whether they are published or not. The documents may come from teaching and research institutions in France or abroad, or from public or private research centers.
L'archive ouverte pluridisciplinaire HAL, est destinée au dépôt et à la diffusion de documents scientifiques de niveau recherche, publiés ou non, émanant des établissements d'enseignement et de recherche français ou étrangers, des laboratoires publics ou privés. 


\title{
Sea lilies in spring: Crinoid diversification during the Early Ordovician
}

Thomas E. Guensburg ${ }^{1}$, James Sprinkle ${ }^{2}$, Rich Mooi $^{3}$, Forest Gahn ${ }^{4}$, Bertrand Lefebvre ${ }^{5}$

${ }^{1}$ IRC, Field Museum, 1400 South Lake Shore Drive, Chicago, IL 60605

(tguensburg@fieldmuseum.org)

${ }^{2}$ Department of Geological Sciences, Jackson School of Geosciences, University of Texas, 1 University Station C1100, Austin, TX 78712-0254 (echino@jsg.utexas.edu)

${ }^{3}$ Department of Invertebrate Zoology \& Geology, California Academy of Sciences, 55 Music Concourse Drive, San Francisco, CA 94118 (rmooi@calacademy.org)

${ }^{4}$ Department of Geology, Brigham Young University--Idaho. 525 South Center Street, Rexburg, ID 83460 (gahnf@byui.edu)

${ }^{5}$ UMR 5276 LGLTPE, Université Claude Bernard, Lyon 1, France (bertrand.lefebvre@univlyon1.fr)

\begin{abstract}
The many Early Ordovician crinoid discoveries over the past 30 years signal a largely undocumented crinoid radiation totalling a more than five-fold increase in diversity, an important event in crinoid history. Camerate, cladid, and disparid clades had emerged by the Late Tremadocian Series, early during this time. These finds provide data for character analysis in phylogenetic reconstructions, particularly those aimed at identifying early branching within the crinoid tree. Early Ordovician crinoids comprised among the earliest-known benthic invertebrates to exploit food resources high above the substrate. Significantly, they were also among the largest known faunal elements during this time. A tentative listing of Early Ordovician crinoids and their distributions is provided; this compendium is subdivided into time slices with Laurentian and global stratigraphic units.
\end{abstract}

\section{Introduction}


Prolific, diverse, and abundant Late Ordovician crinoid faunas have long implied an extensive but largely unknown prior record. Just a handful of Early Ordovician taxa were described by the end of the $20^{\text {th }}$ century (Ubaghs, 1969, 1983; Strimple and McGinnis, 1972; Donovan and Cope, 1989). Dozens of new Early Ordovician taxa have been discovered over the past 30 years (Table 1). Formal study of these, and their significance in understanding crinoid origins and affinities, are works in progress. Long fieldwork, coupled with difficult preparation, has slowed the process. The Tremadocian discoveries are largely described (Guensburg and Sprinkle, 2003; 2009; Guensburg, 2012; Guensburg et al., 2019). A majority of the Floian taxa are not formally described but have been assigned to subclass and, where possible, lower rank taxa. Enough is now known to provide a preliminary accounting of this largely unrecognized radiation of Early Ordovician crinoids.

An important consideration for this study concerns dating of Early Ordovician rocks through improved global biostratigraphic control. A more finely resolved framework for early crinoid occurrences based upon trilobite biostratigraphy in the Great Basin, western United States, is available (Adrain et al., 2009; Adrain et al., 2014). Most critically, stage boundaries for the crinoidbearing Early Ordovician Ibexian Series in Laurentia have been shifted upward relative to the global standard (Walker et al., 2018). In ascending order, these stages are the Stairsian, Tulean, and Blackhillsian. The new data indicate the entire Stairsian stage and lower $80 \%$ of Tulean stage are equivalent to the upper Tremadocian stage of the global standard (Walker et al., 2018). The Floian in Laurentia includes the uppermost Tulean and all of the Blackhillsian stages. The distribution of Early Ordovician crinoids with adjusted stratigraphic data are provided in Table 1.

Materials and repositories.-Figured specimens are housed in the Field Museum (PE), Chicago, Illinois, Idaho Museum of Natural History (IMNH IP-), Pocatello, Idaho, Non-vertebrate Paleontology Laboratory (NPL TX_), University of Texas, Austin, Texas, Palaeontological Collections (UCBL-FSL), Lyon 1 University, Villeurbanne, France, and Paleontology Repository (SUI), University of lowa, lowa City, lowa.

\section{Early crinoid morphology and establishment of major crinoid clades}


Stratigraphic and preliminary phylogenetic evaluation make it possible to hypothesize a sequence of events during which characters first appear within different crinoid lineages. These provide evidence for evaluating the likelihood as to whether similarity among these lineages reflects homology or homoplasy. Here, we apply a broad-brush approach simply to highlight timing of intermediate morphologies that are precursors to those that characterize major crinoid clades, rather than discuss individual characters in detail. We are aware of the shortcomings of this approach, and the need for formal phylogenetic analysis, but this process awaits more formal descriptive data.

Tremadocian diversification of major clades. -The earliest-known crinoids appear during the upper portion of the Tremadocian Series (Stairsian Stage of Laurentia) (Adrain et al., 2014), an estimated $481 \mathrm{Myr}$, and four million years after the Cambro-Ordovician boundary (Walker et al., 2018). The transitional nature of these fossils stands out.

In many ways, taxa of this assemblage exhibit more commonality than later faunas. Stalks are pentameric and calyces have fixed interbrachial plate fields. In particular, arm construction is similar, and includes internal calcified floor plates with podial pores, brachials with secondary aboral grooves, and two-tiered cover plates (Guensburg, 2012; Guensburg et al., 2019). Tremadocian crinoid axial arm constructs (floor, cover plates) resemble certain non-blastozoan pentaradiate echinoderms of the Cambrian rather than later crinoids. All earliest-known taxa (Apektocrinus, Glenocrinus, Titanocrinus) possess lateral plate fields in their arms. None of the Tremadocian crinoids expresses pinnules.

The cup construction of earliest camerate-like taxa, called protocrinoids (Glenocrinus, Titanocrinus), differs from other Tremadocian taxa. The mid-cup consists of many non-differentiated plates that separate ray plating from the cup base circlet. In addition, the posterior interray is wide and extends to the stalk, where a gap plate (or plates) interrupts the cup base circlet. This information has been used to propose the Dual Reference Homology System (Guensburg and Sprinkle, 2003), a modification of the long-used Carpenter (1879) system.

Diversification into clades familiar to paleontologists today had begun but data indicating how these are interrelated is scanty and perplexing. Protocrinoids and other taxa express expanded tegmens without articulating cover plates, a camerate character. Assignment of cladid-like forms is based upon differentiated sub-C-ray "anal" plating. Earliest disparid-like and later early camerate-like taxa express a posterior plate series projecting from the C-ray and extending up an 
anal sac or tegmen (see Guensburg, 2012; Gahn, 2015). Data from as yet undescribed taxa are needed.

Floian and first typical Paleozoic crinoids. - Early Floian taxa express more organized cup plating but some retain Tremadocian-like arm morphology (Fig. 2). Camerate, cladid, and disparid morphology typical of Middle and Late Ordovician crinoids was present by the end of the Floian (Blackhillsian Stage of Laurentia), approximately 470 Myr (Adrain et al., 2009) (Walker et al., 2018). Stalks show the earliest evidence of holomerism, which evolved independently in each clade. Cup plating becomes more regular and standardized (Donovan and Cope, 1989). Arms assume crownward morphology, that is, without floor or lateral plating, which also evolved independently in each clade. Latest camerates in this sequence (Celtocrinus, Proexenocrinus) exhibit pinnulate arms and ray branching at fixed primibrachial three and holomeric columnals, but surprisingly, one taxon expresses floor plates in pinnules (Proxenocrinus). Disparids possess fewer fixed brachial, interbrachial and posterior interray plates (Inyocrinus, Ramseyocrinus). Arms become free above the radials ("compound radial" terminology is not accepted here), and an elongate anal sac characterizes most taxa. Cladids include a number of taxa in which cup plating is more regular and interbrachial plate fields are small or absent (Compagicrinus, Elpasocrinus). The late Floian (Blackhillsian Stage) cladid record is diverse and includes dendrocrinid-like forms, hybocrinids, two other monocyclic forms, one with branched arms, a porocrinidlike taxon, and another dicyclic form with atomous arms.

A curious aspect of many early crinoids is their large size relative to other faunal elements such as brachiopods and nearly all trilobites (Figs. 1, 2). Crowns can be several centimeters in height, and stalks 10 s of centimeters in length, with a maximum known stalk length of over $60 \mathrm{~cm}$. Along with a few poriferans, nautiloid cephalopods, crinoids and a few blastozoans represent the largestknown and most common faunal elements in these Laurentian Tremadocian occurrences. By comparison, associated brachiopod taxa are no more than $1 \mathrm{~cm}$ across.

\section{Early crinoid diversification in the context of the Ordovician Radiation}

There is a diversity of opinions as to how to characterize the marine invertebrate radiation during the Ordovician (most recently Servais and Harper, 2018; Stigall et al., 2019; Edwards, 2019). Crinoids first appear during the Tremadocian Series, coincident with radiations of other characteristic Paleozoic 
faunal elements such as graptolites, chitinozoans, gastropods, and cephalopods (Stigall et al., 2019) during the initial phase of the Ordovician Radiation. This radiation took place prior to the appearance of characteristic Paleozoic faunal elements such as bryozoans, rugose and tabulate anthozoans, and many brachiopods.

It is important to recognize the scale of the previously unrecognized early crinoid component of the Ordovician Radiation. The present list (Table 1) shows a more than five-fold increase in previously known Early Ordovician crinoid diversity, with most of the increase during the Floian. This represents one of the most significant diversification events in crinoid history.

The expanded crinoid record invites inquiry into when and how the crinoid clade might have originated. Probabilistic modelling indicates a Cambrian origin (Wright, 2018). Tremadocian crinoids express characters found among early nonblastozoan pentaradiate echinoderms of the Cambrian (above), suggesting proximity to the crinoid node (Guensburg, 2012). In our view, a diagnostic crinoid level of organization requires at least two apomorphies: "true arms" bearing left and right somatocoel extensions (sensu David and Mooi, 1999; Guensburg et al., 2019), and a pentameric stalk.

It is a narrow morphological gap from this "minimalist" diagnosis of a crinoid to Tremadocian crinoids, and a differentiated ray plate series and calyx base circlet could have co-evolved during this process. With underlying soft-tissue anatomy already in place, it can be postulated that functional requirements produced rapid evolution of these traits. The four million years at the base of the Ordovician for which we have no crinoids yet may have been sufficient for these changes to have evolved from pre-crinoid ancestry, but it is also likely that even earlier taxa expressing some nascent features of the crinoid clade existed in the Cambrian, such as in Camptostroma with its short "proto-arms" (Durham, 1966), and possibly the enigmatic Echmatocrinus (see Sprinkle and Collins, 2011).

\section{Paleobiogeography of Early Ordovician crinoid diversification}

Early Ordovician crinoids ranged across a variety of paleoenvironmental settings, from siliciclastic-dominated mobile substrates in high latitude Gondwana and Avalonia to largely carbonate-dominated mobile and hard substrate settings of equatorial Laurentia (Blakey, 2020). However, intensive fieldwork in several regions of the globe produced different results in terms of diversity and timing of origination (Guensburg and Sprinkle, 1992; Lefebvre and Fatka, 2003; Lefebrvre 
et al., 2013; inter alia). Laurentian localities yield a high diversity fauna, including the earliest-known crinoids. The Great Basin of the western United States has been particularly productive for Laurentian crinoids (Guensburg and Sprinkle, 2003, 2009; Guensburg, 2012; Guensburg et al., 2019). Avalonian/Gondwanan localities produce many echinoderms, including many stalked blastozoans, but few crinoids (Lefebvre et al., 2013).

Regional, but temporally persistent environmental conditions, accompanied the Early Ordovician crinoid radiation in Laurentia. First, geochemical proxies indicate higher oxygen levels in widespread shelfal seas during this time (Edwards, 2019). Oxygen levels were enhanced by cyanobacterial respiration emanating from microbial buildups, also common in this setting. Next, lithified substrates or hardgrounds developing on the microbial buildups and associated intraclastic limestones (flat pebble conglomerates) provided expansive living space (Church, 1974; Wilson et al., 1992; Guensburg and Sprinkle, 1992; Datillo, 1993; Sprinkle and Guensburg, 1995). Direct evidence shows that early crinoids exploited these surfaces using polyplated encrusting-type holdfasts.

\section{Acknowledgements}

We thank Sergey Rozhnov and colleagues at the Paleontological Institute, Russian Academy of Sciences, for hosting the $10^{\text {th }}$ European Echinoderm Conference, and for encouraging work on this paper. We also thank and for constructive reviews.

\section{References}

Ausich, W.I. 1986. Crinoids of the Al Rose Formation (Early Ordovician, Inyo County, California, U.S.A). Alcheringa, v. 10, p. 217-224.

Adrain, J.M., McAdams, N.E.B., and Westrop, S.R. 2009. Trilobite biostratigraphy and revised bases of the Tulean and Blackhillsian Stages of the Ibexian Series, Lower Ordovician, western United States. Memoirs of the Association of Australasian Palaeontologists, v. 37, p. 541-610.

Adrain, J.M., Westrop, S.R., Karim, T.S., and Landing, E. 2014. Trilobite biostratigraphy of the Stairsian Stage (upper Tremadocian) of the Ibexian Series, Lower Ordovician, western United States. Memoirs of the Association of Australasian Palaeontologists, v. 45, 167-214. 
Blakey, D. Deep Time Maps--maps of ancient Earth: https://deeptimemaps.com/. Accessed February 3, 2020.

Carpenter, P.H. 1879. Oral and apical systems of crinoids. Quarterly Journal of Microscopic Science, v. 8, p. 351-383.

Church, S.B. 1974. Lower Ordovician patch reefs in western Utah. Brigham Young University Geology Studies, v. 21, p. 41-62.

Dattilo, B.F. 1993. The Lower Ordovician Fillmore Formation of Western Utah; storm-dominated sedimentation on a passive margin. Brigham Young University Geology Studies, v. 39, p. 71-100.

David, B., and Mooi, R. 1999. Comprendre les échinodermes: la contribution du modèle extraxial-axial. Bulletin de la Société Géologique de France, v. 170, p. 91-101.

Donovan, S.K., and Cope, C.W. 1989. A new camerate crinoid from the Arenig of south Wales. Palaeontology, v. 32, p. 101-107.

Durham, J.W. 1966. Camptostroma, and Early Cambrian supposed scyphozoan referable to Echinodermata. Journal of Paleontology, v.40, p. 1216-1220.

Edwards, C.T. 2019. Links between early Paleozoic oxygenation and the Great Ordovician Biodiversification Event (GOBE): a review. Paleoworld, v. 28, p. 37-50.

Gahn, F. 2015. Homological and phylogenetic implications of a disparid-like posterior interray among lower Ordovician camerate crinoids. In S. Zamora and I. Rabano (eds.), Progress in Echinoderm Paleobiology. Instituto Geologico y Minero de Espana, Cuadermos del Museo Geominero, v. 19, p. 59-65.

Guensburg, T.E. 2010. Alphacrinus new genus and the origin of the disparid clade. Journal of Paleontology, v. 84, p.1209-1216.

Guensburg, T.E. 2012. Phylogenetic implications of the oldest crinoids. Journal of Paleontology, v. 86, p. 455-461.

Guensburg, T.E., and Sprinkle, J. 1992. Rise of echinoderms in the Paleozoic Evolutionary Fauna. Geology, v. 20, p. 407-410.

Guensburg, T.E., and Sprinkle, J. 2003. The oldest known crinoids and a new crinoid plate homology system. Bulletins of American Paleontology, v. 364, p. 1-43.

Guensburg, T.E., and Sprinkle, J. 2009. Solving the mystery of crinoid ancestry: New fossil evidence of arm origin and development. Journal of Paleontology, v. 83, p. 350-364. 
Guensburg, T.E., and Waisfeld, B. 2015. South America's earliest (Ordovician, Floian) crinoids. Journal of Paleontology, v. 89, p. 622-630.

Guensburg, T.E., Sprinkle, J., Mooi, R., Lefebvre, B., David, B., Roux, M., and Derstler, K. 2019. Athenacrinus n. gen. and other early echinoderm taxa inform crinoid origin and arm evolution. Journal of Paleontology, online version: doi 10.1017/jpa.2019.87

Hicks, H.L., 1873. On the Tremadoc rocks in the neighborhood of St. David's, south Wales, and their fossil contents. Quarterly Journal of the Geological Society of London, v. 29, p. 39-52.

Jobson, L. and Paul, C.R.C. 1979. Compagicrinus fenestratus, a new Lower Ordovician inadunate crinoid from North Greenland. Rapport Geologiske Undersøgelse, v. 91, p. 71-81.

Kelly, S.M., and Ausich, W.I. 1979. A new name for the Lower Ordovician crinoid Pogocrinus Kelly and Ausich. Journal of Paleontology, v. 53, p. 1433.

Lefebvre, B., and Fatka, O. 2003. Palaeogeographical and palaeoecological aspects of the Cambro-Ordovician radiation of echinoderms in Gondwanan Africa and peri-Gondwanan Europe. Palaeogeography, Palaeoclimatology, Palaeoecology, v. 195, p. 73-97.

Lefebvre, B., Sumrall, C.D., Shroat-Lewis, R.A., Reich, M., Webster, G.D., Hunter, A.W., Nardin, E., Rozhnov, S.V., Guensburg, T.E., Touzeau, A., Noailles, F., and Sprinkle, J. 2013. Palaeobiogeography of Ordovician echinoderms. In D.A.T. Harper and T. Servais (eds.), Early Palaeozoic Biogeography and Palaeogeography. Geological Society, London, Memoirs, v. 38, p. 173-198.

Sprinkle, J., and Colins, D. 2011. Revision of Echmatocrinus from the Middle Cambrian Burgess Shale of British Columbia. Lethaia, v. 31-p. 261-282.

Sprinkle, J., and Guensburg, T.E. 1995. Origin of echinoderms in the Paleozoic evolutionary fauna; the role of substrates. Palaios, v. 10, p. 437-453.

Sprinkle, J., and Wahlman, G.P. 1994. New echinoderms from the Early Ordovician of west Texas. Journal of Paleontology, v. 68, p. 324-338.

Servais, T., and Harper, D.A.T. 2018. The Great Ordovician Biodiversification Event. Lethaia, v. 51, p. 151-164.

Stigall, A.I., Cole, C.T., Freeman, R.L., and Rassmussen, C.M.O. 2019. Coordinated biotic and abiotic change during the Great Ordovician Biodiversification Event: Darriwilian assembly of early Paleozoic building blocks. Palaeogeography, Palaeoclimatology, and Palaeoecology, v. 530, p. 249270. 
Strimple, H.L., and McGinnis, M. 1972. A new camerate crinoid from the Al Rose Formation, Lower Ordovician of California. Journal of Paleontology, v. 46, p. 72-74.

Ubaghs, G. 1969. Aethocrinus moorei Ubaghs, n. gen., n. sp., le plus ancien crinoïde dicyclique connu. The University of Kansas Paleontological Contributions, Paper 38, p. 1-25.

Ubaghs, G. 1983. Echinodermata. Notes sur les échinodermes de I'Ordovicien inférieur de la Montagne Noire (France). In R. Courtessole, L. Marek, J. Pillet, G. Ubaghs and D. Vizcaïno (eds.), Calymenina, Echinodermata et Hyolitha de l'Ordovicien inférieur de la Montagne Noire (France méridionale). Mémoire de la Société d'Etudes Scientifiques de l'Aude, 3356.

Walker, J.D., Geissman, J.W., Bowring, S.A., and Babcock, L.E., compilers. 2018. Geological Time Scale, v. 5.0: Geological Society of America, https://doi.org/10.1130/2018. Accessed on February 20, 2020.

Wilson, M.A., Palmer, T.J., Guensburg, T.E., Finton, C.D., and Kaufman, L.E. 1992. The development of an Early Ordovician hardground community in response to rapid sea-floor calcite precipitation. Lethaia, v. 25, p. 19-34.

Figure captions:

Figure 1. Selected Tremadocian crinoids, posterior views: (1) camerate-like Titanocrinus sumralli Guensburg and Sprinkle, 2003, distal stalk and holdfast, Field Museum, PE 52754; (2) Glenocrinus globularis Guensburg and Sprinkle, 2003, crown and proximal stalk, PE 52733, posterior at center, no differentiated posterior plating; (3) disparid-like Alphacrinus mansfieldi Guensburg, 2010, posterior plating at center originating from the $C$ ray first primibrachial (anibrachial), PE 52743; (4) cladid-like Aethocrinus moorei Ubaghs, 1969, posterior plating at right, originating below $C$ ray radial, UCBL-FSL 424987.

Figure 2. Selected Floian crinoids, posterior views: $(\mathbf{1}, \mathbf{2})$ Early Floian (Early Blackhillsian) camerates, (1) finely ornamented camerate, large domed tegmen, no visible cover plates, posterior plating arising from the $\mathrm{C}$ ray, IMNH IP-277/856, (2) stellate-plated disparid, IMNH 
IP-278/857; (3-6) Late Floian (Late Blackhillsian) crinoids, (3) Late Floian hybocrinid, NPL 1780TX14, (4) monocyclic cladid, PE 52755, (5) porocrinidlike cladid, NPL 1777TX12, (6) diplobathrid camerate Proxenocrinus inyoensis Strimple and McGinnis, 1972, among the earliest-known pinnulate crinoids, SUI 134561a.

Table 1. Early Ordovician crinoid compendium. Laurentian Stage boundaries have shifted upward, with change in taxon range indicated here. This list represents a conservative minimum estimate of available taxa. Numerous specimens remain too obscured by matrix to consider for this list.

TIME SLICE/TAXON

PALEOCONTINENT

(L=Laurentia, G=Gondwana,

$A=$ Avalonia)

Late Tremadocian Stage 481-479 Ma (Stairsian Stage)

Camerate-like

Titanocrinus sumralli Guensburg and Sprinkle, 2003

Eknomocrinus wahwahensis Guensburg and Sprinkle, 2003

Glenocrinus globularis Guensburg and Sprinkle, 2003

Cladid-like

Apektocrinus ubaghsi Guensburg and Sprinkle, 2009

Disparid-like

Alphacrinus mansfieldi Guensburg, 2012

Athenacrinus broweri Guensburg et al., 2019

\section{Latest Tremadocian to Earliest Floian 479-475 Ma \\ (Tulean Stage)}

Camerates

Cnemecrinus fillmorensis Guensburg and Sprinkle, 2003

Cladids 
Aethocrinus moorei Ubaghs, 1969

Fillmore hybocrinid

Disparids

Pogonipocrinus antiquus (Kelly and Ausich, 1979)

Fillmore iocrinid ornamented

Fillmore iocrinid smooth

Fillmore iocrinid smooth, tiny

Undescribed lower Fezouata disparid

Early to Late Floian 475-470 Ma (Blackhillsian Stage)

Camerates

Adelphicrinus fortuitus Guensburg and Sprinkle, 2003

Celtocrinus ubaghsi Donovan and Cope, 1989

A

Reduced-interray camerate

Dugway flat cup-base camerate

Green Canyon camerate

Habrotecrinus ibexensis Guensburg and Sprinkle, 2003

Finely ornamented camerate

Proexenocrinus inyoensis Strimple and McGinnis, 1972

Quechuacrinus ticsa Guensburg and Waisfeld, $2015 \quad$ G

Stellate domed-tegmen camerate

Cladids

Arbuckle Group dendrocrinid

Compagicrinus fenestratus Jobson and Paul, 1979

Elpasocrinus radiatus Sprinkle and Wahlman, 1994

Fillmore/Ninemile thin-armed atomous

Fillmore atomous thick-armed

Fillmore atomous thin-armed

Fillmore moncyclic, branched arms

Garden City stellate dendrocrinid

Garden City smooth dendrocrinid

Fillmore/Ninemile hybocrinid

Ninemile porocrinid 
Disparids

Arbuckle Group short calyx

Fillmore/Garden City heavy armed

Fillmore/Garden City inflated sac

Fillmore/Garden City smooth plated

Fillmore thick plated iocrinid

Fillmore small iocrinid

Fillmore short armed ?iocrinid

Garden City flat based, 10-armed

Garden City heavy plated iocrinid

Garden City ornamented

Garden City long-armed, single branching

Garden City tumid, long-armed

Garden City Alphacrinus-like disparid

Ninemile ornamented iocrinid

Peculiar Ninemile and Fillmore ?disparid

Ramseyocrinus argentinus Guensburg and Waisfeld, 2015

Ramseyocrinus cambriensis (Hicks, 1873)

Ramseyocrinus vizcainoi Ubaghs, 1983

G

Upper Fezouata Ramseyocrinus

G

Inyocrinus strimplei Ausich, 1986 